Matematikai Közlemények

IX. kötet, 2021

doi:10.20312/dim.2021.05

\title{
A háromszög köré- és beírt szabályos háromszögéről
}

\begin{abstract}
Hajdu Endre
Soproni Egyetem

ÖSSZEFOGLALÓ. Tetszőleges háromszögbe irható szabályos háromszög úgy, hogy a beírt háromszög csúcsai az adott háromszög különböző oldalaira illeszkedjenek. Az ilyen beírt háromszögek közül keressük a legkisebbet, amelyre két új szerkesztési módszert is adunk. Továbbá megmutatjuk, hogy az adott háromszög területe a maximális és a minimális (köré írt, ill. beírt) háromszög területének mértani közepe.
\end{abstract}

\begin{abstract}
For any triangle, there exist an inscribed equilateral triangle, whose vertices are on different sides of the triangle. I give two various methods for constructing the smallest of such inscribed triangles. Moreover, we show that the area of the consider triangle is the geometric mean of the maximal and minimal (circumscribed and inscribed) triangles.
\end{abstract}

\section{Bevezetés}

Évtizedek során összegyűlt geometriai följegyzések, feladatok, megoldások átnézése, selejtezése során bukkantam egy régi ötletemre: adott három, nem egy egyenesen lévő pont, szerkesztendö a legnagyobb szabályos háromszög, melynek egy-egy oldala az adott pontok valamelyikét tartalmazza. Ezen a feladaton tünődve jutottam egy rokon, de minimum keresést jelentő példára: egy tetszőleges háromszögbe hogyan szerkeszthető legkisebb szabályos háromszög, melynek csúcsai az adott háromszög oldalaihoz illeszkednek? Ellentétben a közismertnek mondható, háromszögbe írható legkisebb kerületü háromszög feladatával (talpponti háromszög [1]), ez kevéssé ismert, tárgyalt téma, ezért lehet indokolt a vonatkozó irodalomban [2], [3], [4] talált megoldásoktól különböző alábbi szerkesztéseim ismertetése. A két megoldás közül a második annyiban mondható sajátságosnak, hogy a minimumkeresés céljából egy maximális méretü háromszöget kell előállítani.

A háromszög köré írt legnagyobb szabályos háromszög szerkesztésével és számításával is foglalkozik az anyag. Az adott háromszög területe a másik két háromszög területének mértani közepe.

\section{Első megoldás}

Mint ismeretes, egy adott háromszög valamely $a$ oldalán fölvett $P$ pontját egy szabályos háromszög egyik csúcsául véve, a $b$ oldalon keresett $Q$ csúcsot, a $c$ oldal egyenesének a $P$ körül $\varphi=60^{\circ}$-kal elforgatottja jelöli ki az 1 . ábra szerinti szerkesztés révén. 


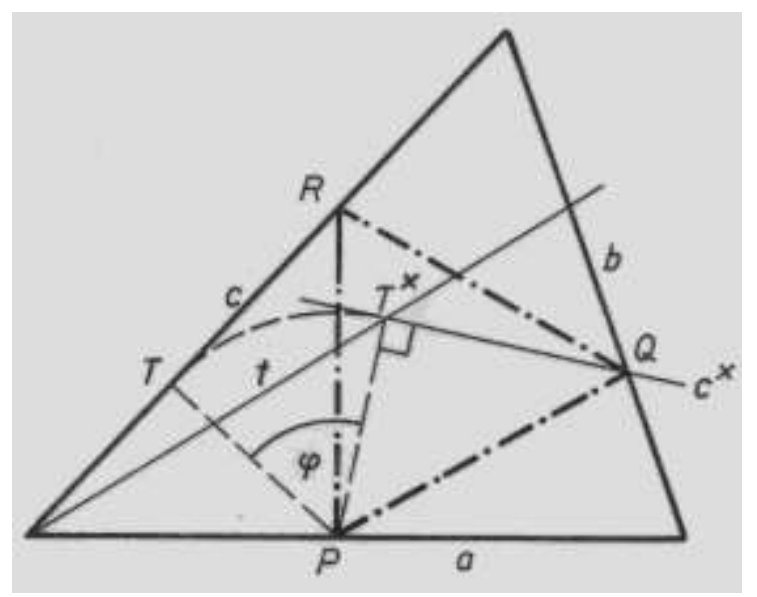

1. ábra

A $Q$ pont ismeretében a $P Q R$ szabályos háromszög megszerkesztése már egyszerü. Az $a$ oldalon fölvett $P$ pont helyzetétől függetlenül, a $T$ talppont $T^{*}$ elforgatottja ugyanarra a $t$ egyenesre esik, a $P T^{*}$-ra merőleges $c^{*}$ egyenes állása is változatlan. Az eredeti föladat az 1. ábra alapján úgy is átfogalmazható, hogy keressük a $P$ pont azon helyzetét, melynél a $P T^{*} Q$ derékszögű háromszög átfogója a legkisebb, ha $P$ befutja az $a$ oldalt. A 2. ábrából kitűnik, hogy az $a$ oldalnak csak a $P_{0} P_{v}$ darabján jelölhető ki $P$. A $P Q Q^{\prime} P^{\prime}$ parallelogrammákhoz tartozó minden $P^{\prime}$ pont egy egyenesre, a $p$-re esik. A $P_{0} P_{v}$ szakasz minden $P$ helyzetéhez tartozik egy $Q^{\prime} P^{\prime}\left(Q^{\prime} \equiv B\right)$ szakasz, s ezek közül a legrövidebb a $p$-re merőleges szakasz.

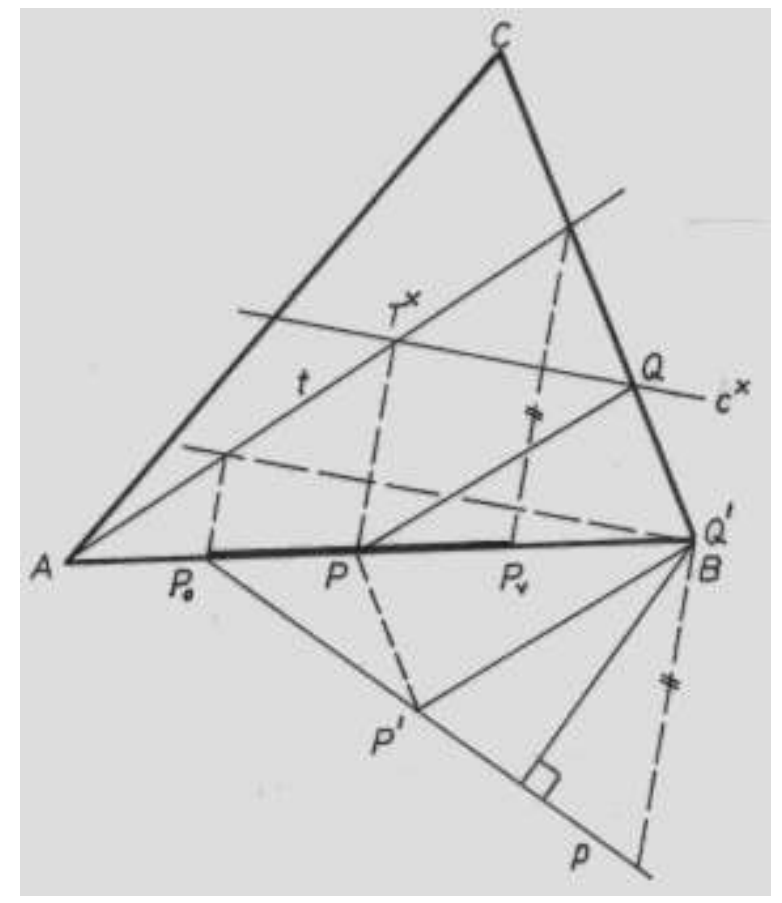

2. ábra

Az eredeti föladat 1. megoldását az imént látottak alapján, a 3. ábra szemlélteti. 


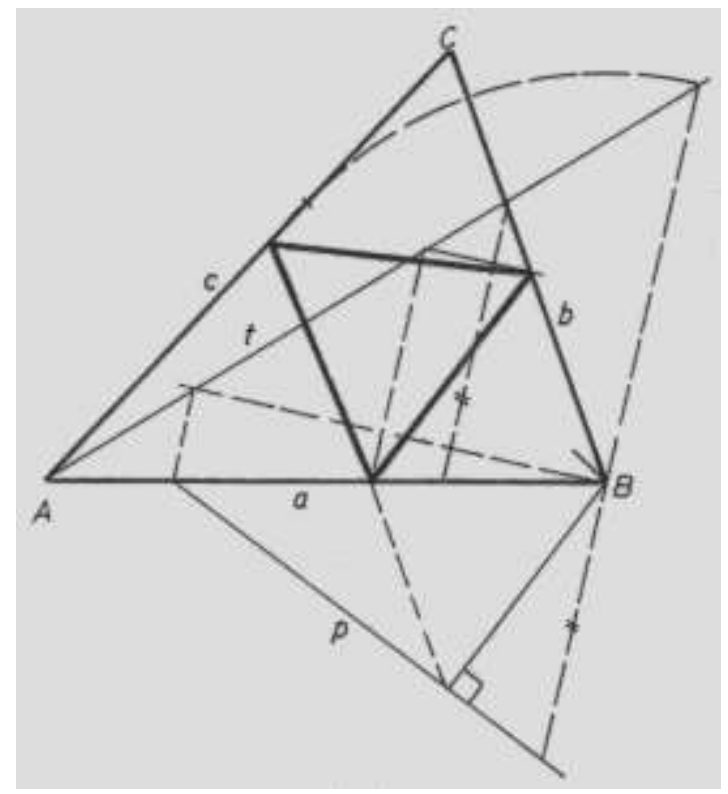

3. ábra

\section{Második megoldás}

Az előző megoldásban szereplő adott háromszögnek feleljen meg most a 4 . ábra $H$ háromszöge, az ismeretlen méretü legkisebb beírt szabályos háromszögének pedig $S$. A második megoldás lényege: az $S$-hez hasonló, tetszőleges méretü szabályos háromszöget veszünk föl, melyre a $H$ háromszöghöz hasonló, de legnagyobb körülírt háromszöget szerkesztünk, majd a kapott háromszöget az adott $H$ méretére kicsinyítjük - vagy nagyítjuk.

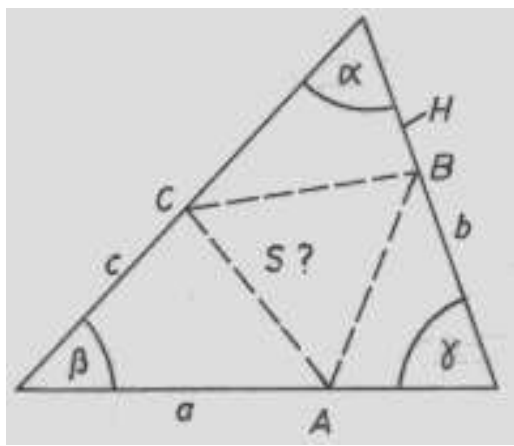

4. ábra

Jelölje most a keresett $S$ legkisebb beírt szabályos háromszög tetszőleges méretü megfelelöjét $S^{*}$, csúcspontjait $A^{*} B^{*} C^{*}$. Az adott háromszög $a$ oldala $a^{*}$ megfelelöjének végpontjai az $A * B^{*}$ és $A * C^{*}$ oldalakra szerkesztett $\gamma$ ill. $\beta$ szögü látóköríveken keresendők, azzal a föltétellel, hogy egymástól mért távolságuk a lehető legnagyobb legyen, mert ha a fölvett szabályos háromszög a köré írt háromszög legkisebb szabályos háromszöge, akkor a beírt háromszöghöz képest a köré írt háromszög maximális (5. ábra). 


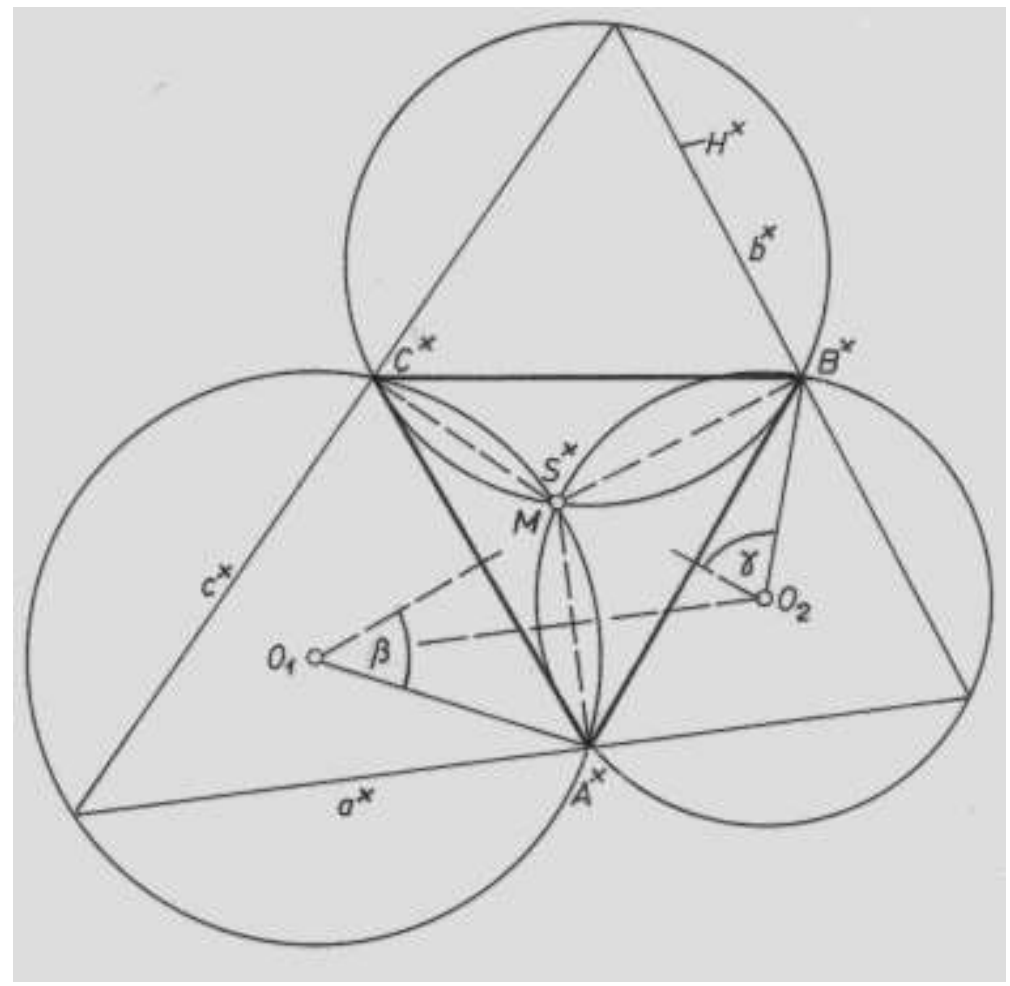

5. ábra

Ez utóbbi a részfeladatnak a megoldása a 6. ábrából következik: két egymást metsző kör egyik $M$ metszéspontján átmenő egyenesnek a körök által határolt darabja $2 a+2 b$ hosszúságú, ahol $2(a+b)$ akkor a legnagyobb, ha az egyenes párhuzamos a kör-középpontokat összekötö egyenessel. $\mathrm{Az} 5$. ábrán e feltétel alapján szerkesztett $a^{*}$ egyenes kimetszi a látókörívek megfelelő pontjait, az $S^{*}$ háromszög köré írt legnagyobb és kívánt alakú háromszögének csúcspontjait. Megemlítendő, hogy az $S^{*}$ háromszög oldalaira szerkesztett látókörívek egy $M$ pontban metszik egymást, mely pont egyben az $A * B * C^{*}$ pontokban a $H^{*}$ oldalaira állított merőlegesek közös pontja is. A keresett $H$ háromszög az 5. ábra olyan kicsinyítésével adódna, melynél a 4. ábrával azonos alakzatot kapnánk.

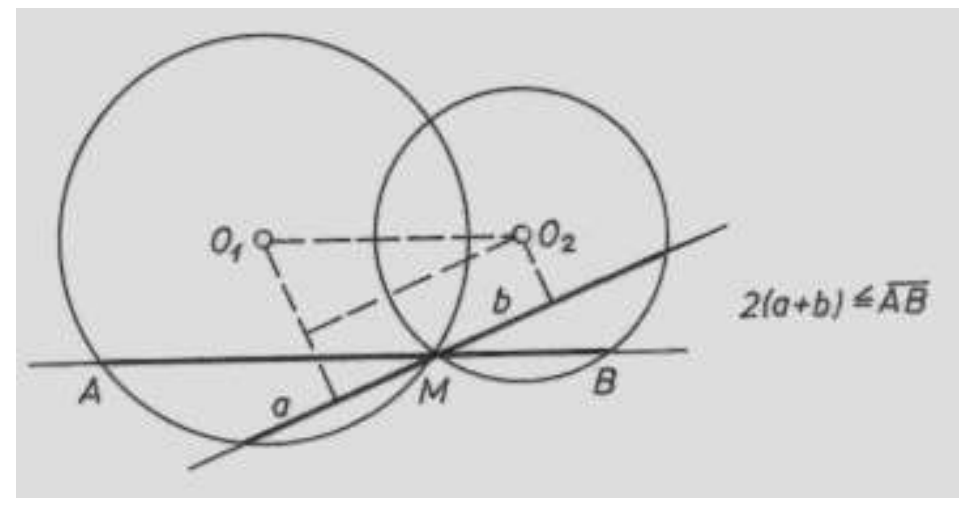

6. ábra

A kicsinyítést mellőzve még egy figyelemre méltó mozgásgeometriai tényre érdemes rámutatni (7. ábra). Ha a keresett háromszögön kívül egy másik beírt szabályos háromszöget is megrajzolunk, ami már nagyobb persze, mint a vastagon rajzolt legkisebb, fölvethető a kérdés: 
elmozgatható-e a beírt háromszög úgy, hogy két csúcsa a megfelelö támaszoldalon marad? Az új háromszög $A_{1} B_{1}$ csúcsa a körülírt háromszög megfelelő oldalain akkor indulhat mozgásnak, ha a momentáncentrum $M_{1}$. Ha a $B_{1} C_{1}$ szakaszát mozgatnánk, a momentáncentrum az $M_{2}$ lenne. A $C_{1} A_{1}$-hez az $M_{3}$ tartozna; mi a helyzet a legkisebb beírt háromszöggel? Egyetlen $M$ momentáncentrum adódik, mert mint láttuk korábban, a legkisebb beírt háromszög esetén a momentáncentrumot kijelölő egyenesek egy pontban metsződnek. Az $M$ pont körül mindkét forgásirányban elforgatható a beírt legkisebb háromszög, míg az egyéb szabályos beírt háromszögek csak egy forgásirányban.

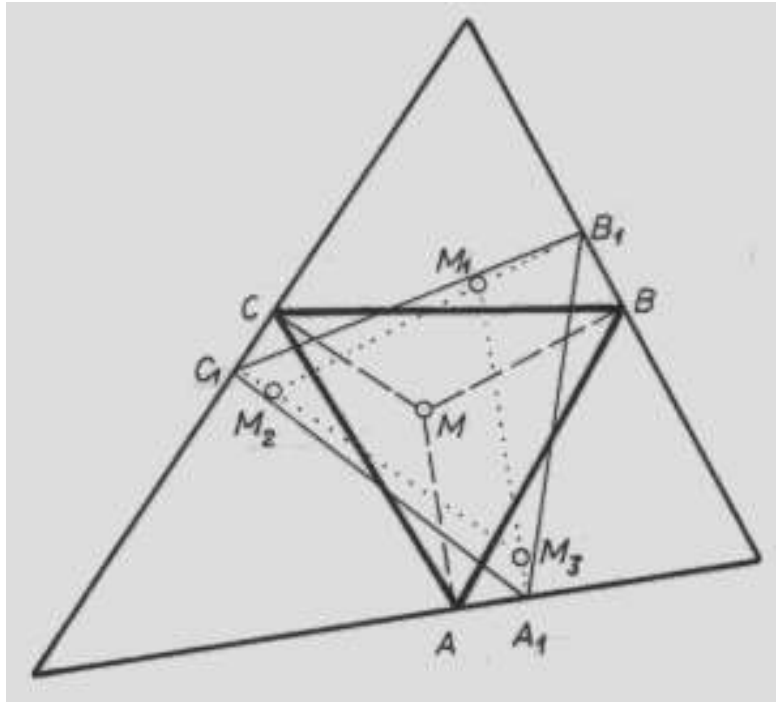

7. ábra

A háromszögbe beírható legkisebb szabályos háromszög szerkesztésénél könnyebb föladat a háromszög köré írt legnagyobb szabályos háromszög szerkesztése; az egyik lehetséges megoldást az 5. ábrán már látott módszer alkalmazását jelenti. Az $A B$, ill. $A C$ oldalhoz tartozó, $60^{\circ}$ látószögü körívek középpontjainak összekötő szakaszával párhuzamos és az $A$ ponthoz illeszkedö egyenes metszi ki a látókörívekböl a keresett legnagyobb, köré írt szabályos háromszög két csúcspontját (8. ábra).

A maximális méretü, köré írt háromszög oldalai párhuzamosak a beírt szabályos háromszög oldalaival, s egyben párhuzamosak azzal a háromszöggel is, melynek csúcsai az adott háromszög oldalaira kifelé szerkeszthető szabályos háromszögek középpontjai. E tény az 5. ábrán alkalmazott, látókörívekkel kapcsolatos szerkesztési módszer alapján látható be. A beírt és a köré írt szabályos háromszög között párhuzamos és centrális hasonlóság áll fenn, az utóbbi centruma $O$. A legnagyobb köré írt háromszög esetén is érvényesek a 7. ábrával kapcsolatban említett tulajdonságok: a csúcsponti támasznormálisok egy pontban metszik egymást, az $M_{b}$ belső és az $M_{k}$ külső metszéspontok általános esetben nem esnek egybe. $\mathrm{E}$ pontok körül a fixnek tekintett $A B C$ háromszöghöz képest a belső háromszög forgatható el $M_{b}$ körül, míg a köré írt háromszög az $M_{k}$ körül, az óra mutató járásával egyező vagy ellentétes forgásirányban. További figyelemre méltó tény, hogy a beírt és köré írt szabályos háromszögek $T_{b}, T_{k}$, valamint az adott háromszög $T_{h}$ területe között az alábbi összefüggés áll fenn:

$$
\frac{T_{k}}{T_{h}}=\frac{T_{h}}{T_{b}}=q
$$




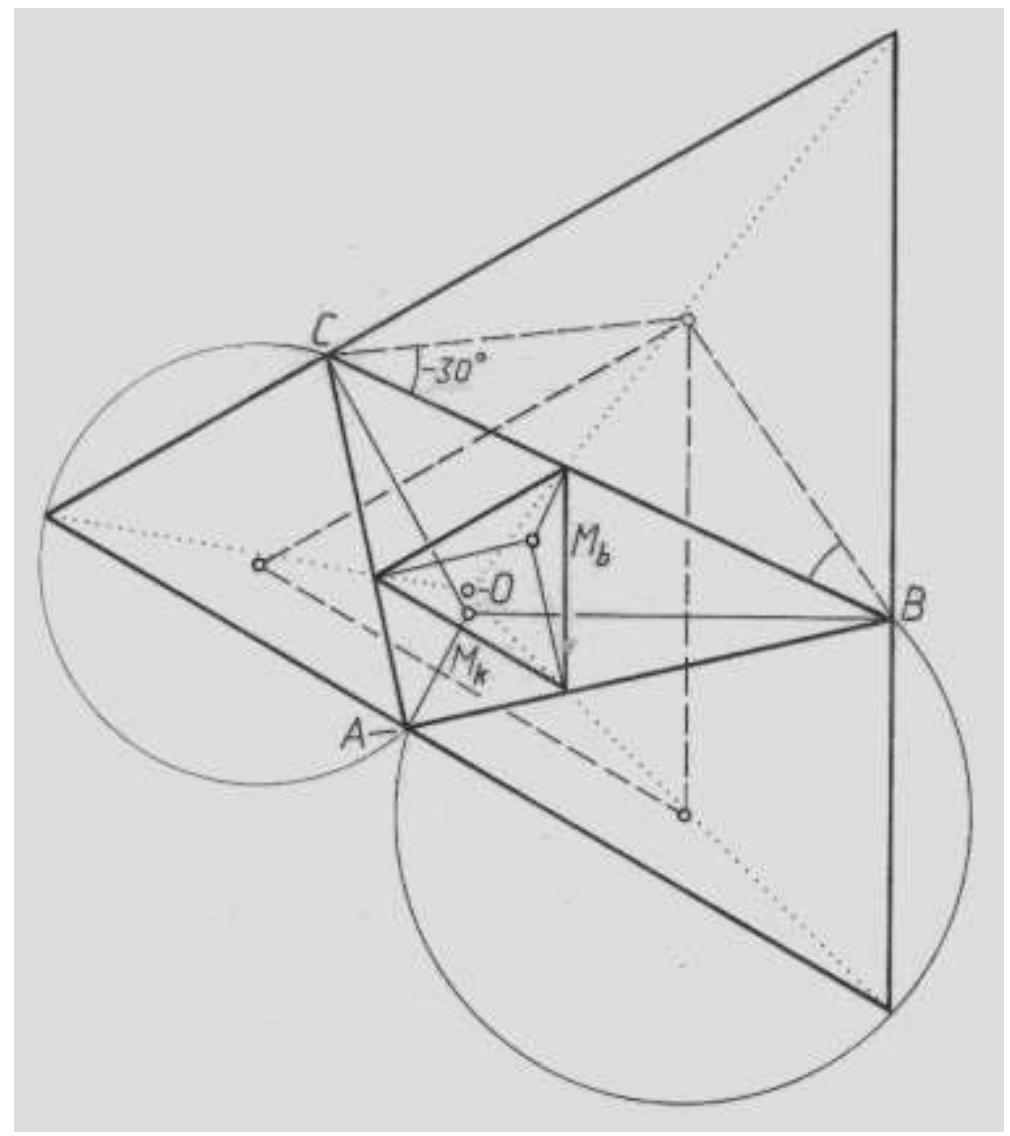

8. ábra

Az adott háromszög területe tehát a beírt, és a köré írt szabályos háromszögek területének mértani közepe, vagyis $T_{h}=\sqrt{T_{b} T_{k}}$. A $q$ hányados függ az adott háromszög alakjától, legkisebb értéke 4, de lehet bármekkora is. Az elmondottakra legegyszerübb példa egy szabályos háromszögbe írt és köré írt szabályos háromszöget szemléltető 9. ábra.

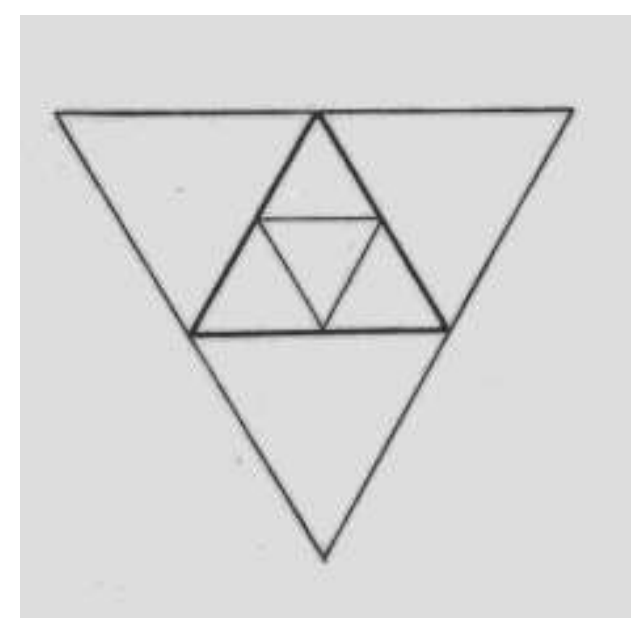

9. ábra

Az adott és a szabályos háromszögek terület-hányadosaira vonatkozó tétel bizonyítására vonatkozó számításokat mellőzve, az eredmények a következők: egy $A B C$ háromszög $a, b$ 
oldalhosszait és az oldalak által bezárt $\gamma$ szöget ismerve, az adott háromszög területe $T_{h}=\frac{a b \sin \gamma}{2}$. A háromszög köré írt legnagyobb szabályos háromszög oldalhossza

$$
L=\frac{2 \sqrt{a^{2}+b^{2}-2 a b \cos \left(\gamma+60^{\circ}\right)}}{\sqrt{3}} .
$$

E háromszög területe

$$
T_{k}=L^{2} \frac{\sqrt{3}}{4}=\frac{a^{2}+b^{2}-2 a b \cos \left(\gamma+60^{\circ}\right)}{\sqrt{3}} .
$$

A legkisebb beírt szabályos háromszögnek az oldalhossza

$$
l=\frac{a b \sin \gamma}{\sqrt{a^{2}+b^{2}-2 a b \cos \left(\gamma+60^{\circ}\right)}},
$$

területe

$$
T_{b}=\frac{\sqrt{3} a^{2} b^{2} \sin ^{2} \gamma}{4\left[a^{2}+b^{2}-2 a b \cos \left(\gamma+60^{\circ}\right)\right]} .
$$

A három háromszögre vonatkozó területhányadosok közös értéke

$$
q=\frac{2\left[a^{2}+b^{2}-2 a b \cos \left(\gamma+60^{\circ}\right)\right]}{\sqrt{3} a b \sin \gamma} .
$$

A hányados alakulását a $\varphi$ szög függvényében ( $a=b$ esetén) a 10. ábra szemlélteti.

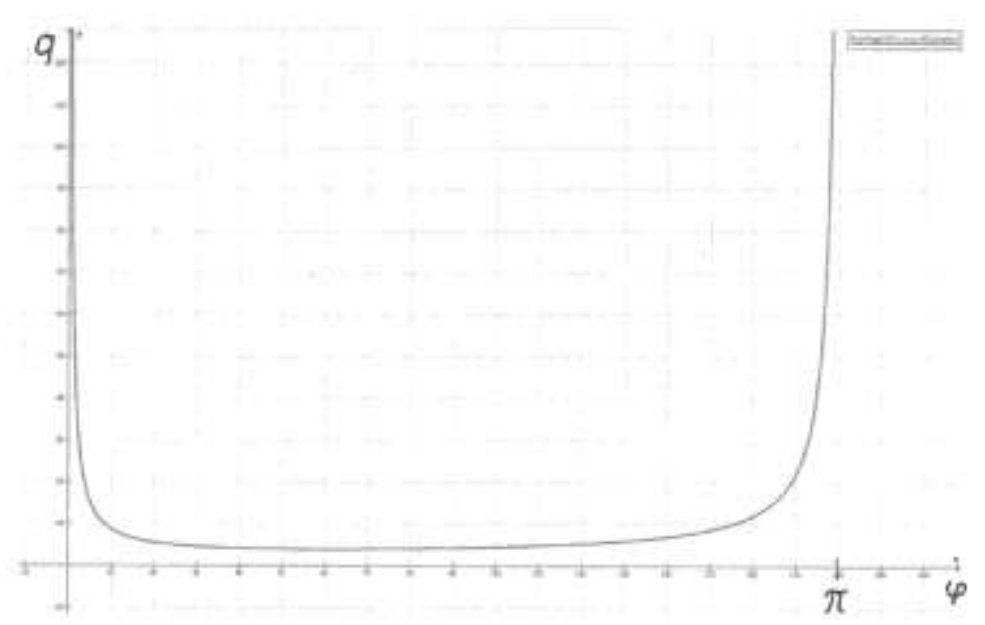

10. ábra

A 11. ábra derékszögü egyenlő szárú háromszögére $q \approx 4,309$. 


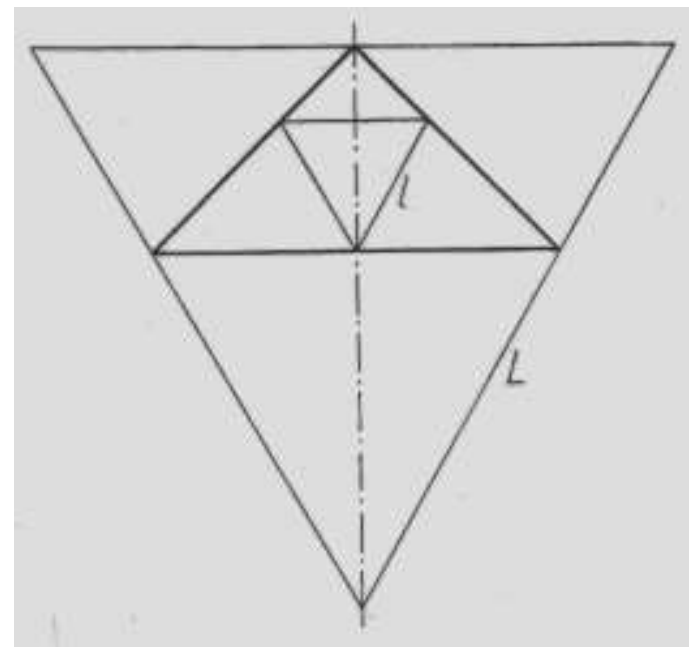

11. ábra

\section{Irodalomjegyzék}

[1] H. Rademacher - O. Toeplitz: Számokról és alakzatokról, Typotex, Budapest, 2010.

[2] Reiman István: Elemi geometriai példatár Tankönyvkiadó Budapest, 1963.

[3] Inscribed equilateral triangle, http://mathafou.free.fr/pbg_en/sol143.html.

[4] Art of Problem Solving, AoPs Online, AoPS Wiki, 2017 AIME I Problems/Problem 15, https://artofproblemsolving.com/wiki/index.php/2017_AIME_I_Problems/Problem_15. 